\title{
Paper, Patronage and Production of Books: Remarks on an 11th Century Manuscript from Central Tibet
}

\author{
Pasang Wangdu
}

\section{1 \\ Introduction}

Book production was already important in Tibet during the bTsan po period. Large scriptoria with scribes and editors supported by the political elite were part of the book culture of the time and materials from Dunhuang provide ample evidence of this. Early post-dynastic materials from Central Tibet show that this practice remained very important after the fall of the Tibetan dynasty. These practices of book production were the direct predecessors of printing workshops. In this paper I will discuss an 11th century manuscript from Ke ru that yields information on this kind of workshop and includes references not only to patronage but also to editorial practices and materials. The Ke ru collection and other manuscripts from lHo kha provide data on Tibetan paper that date back to the 1oth/11th century and show the use of plants from the thymealaeaceae family in paper making. Paper analysis of a number of the nith century manuscripts preserved at Ke ru shows that many were produced with a paper made from Stellera roots ( re lcag pa) and the bark of Daphe/Edgeworthia/Wikistroemia (shog shing/skyems shing) mixed together. There are also a few pure Stellera paper samples, the oldest of which comes from a manuscript dating to the 1oth century (according to both textual evidence and $\mathrm{C}_{14}$ dating).

\section{$2 \quad$ An wth Century Colophon}

Among the fragments preserved at Ke ru lHa khang there is a text of the 'Phags pa 'gro ba thams cad yong su skyob par byed pa'i yongs su sngo ba. The final verses of this text say that it was translated from Sanskrit into Tibetan by mKhan po bidy'a ka ra pra bha (Vidyākaraprabha?) from India together with 


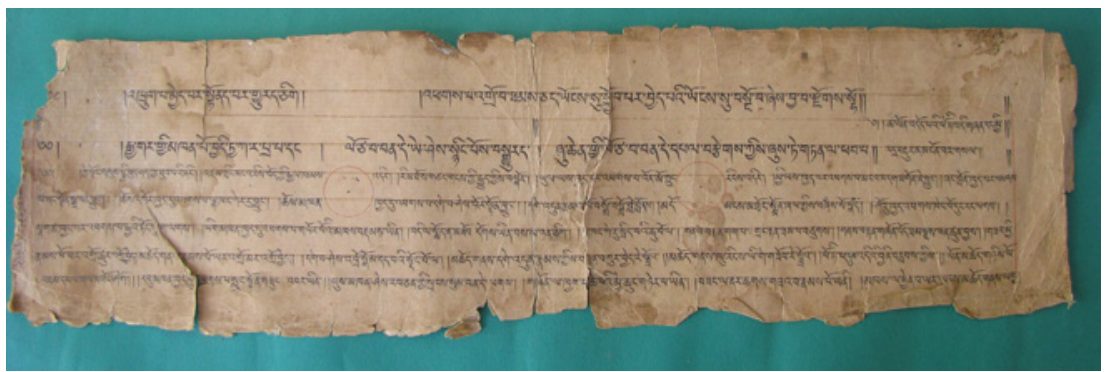

FIGURE 24.1 11th century manuscript from Ke ru Monastery.

PHOTOGRAPH PASANG WANGDU.

the Tibetan translator Lo tsa ba Ban de Ye shes snying po and was edited (zhus gtan la phab) by Ban de dPal brtsegs, translator and chief editor. The colophon of this specific manuscript edition reads as follows:

This text showing the virtue (tsha yon) is special; if you compare it to others this will be clear.

Kye! The apex of three universes (stong) is the southern continent, the land of Saakyamuni where the royal domain of Tibet [is located], with its high peaks and pure land, encircled by glacier mountains. In this land of 'On mo lung ring, which is the most excellent place, appeared the most excellent man, the ruler mGon ne; the most excellent uncle-ministers Zhang ston sgra ben; the most excellent place of worship, the temple of Ke ru; the most excellent abbot dGe shes 'Or ston. It is said that those members of the Buddhist community with their sgro sgro blo blo [sounding recitation] chant many sūtras that awaken spiritual aspirations by seeing. The best of all papers is kheng po dung rang; the best of all inks is tong nag from rGya (China); the best scribe is mKhas brdam of g.Yor po. If you blame this [text], it is not appropriate, don't do it! The Arhat Gag pa built a straight and firm bridge (grang rten) on the river of the universe which is the temple of Ke ru. The Arhat gZhon 'od acted as the bridgesupport (zam sngas, lit. pillow). The lay people ( $g z a^{\prime}$ myi) [constantly] crossed this bridge and the members of the Buddhist community to which offerings were made (lit. 'field of offering') came and went [over the same bridge]. These monks to whom offerings were made were keen to serve and respect $\mathrm{dGe}$ bshes 'Bro sgom who is the tree of the faith. The priest sKu ring was keen to transcribe the letters carefully. Thanks to the blessing of this volume (po ti pha dum) may the patron and priest, [these] 
two, encounter the face of Manjuśrī. The excellent images were drawn by sLung ston gzungs (?) 'bar. The editor was the wise Srangs sum ban de. The short young man with great endurance was the manager [of the operation]. The lay people were kind and persistent. The priests from Yar lungs were learned and sharp.

tsha yon 'dod pa'i po ti'di gzhan dang mi'dra sdur na mngon par gsall/

kye stong gsum sbyi phud shag kya thub pa'i zhing//'dzam gling mnga' ris bod gyi rgyal khams 'dir//ri mtho sa gtsang gangs kyi rgyud kyis bskor// yul las khyad par phags pa'on mo klung rings 'dir//myi las khyad par'phags pa mnga'bdag mgon ne 'byung//

Zhang blon khyad par 'phags pa zhang ston sgra ban byung//chos dkor khyad du'phags pa ke ru lha khang byung// chos mkhan khyad du 'phags pa dge shes 'or ston byung// dge 'dun rnams po bsgro bsgro blo blo nas// mdo mangs mthong smon zha lgyis bzhis so skad// sho'u khyad 'phags kheng po dung rang lags//snag tsha khyad par 'phags pa rgya'i stong snag lags// yig mkhan khyad du 'phags pa g.Yor po'i mkhas brdams yin//'di la smod na mtho' dogs yin pas ma nyan cig// lha khang ke ru srid pa'i chu bo la// gnas brtan gag pa grang rtan zam pa btsugs// gnas brtan gzhon 'od zam sngas phan btsun byas//gza' myi rnam spo phar'gro tshur 'gro byed// mchod gnas rnams po yar 'gro mar 'gro byed// dge shes 'bro sgom dad pa'i sdom po la// mchod gnas dge 'dun rnams kyis bsnyan bkur byed re sbro'// mchod gnas khu rings y age gzob re sbro'// po ti pha dum 'di'i byin brlabs khyis//yon mchod gnyis po'jam dpal zhal mthong shog//dbu mkhan khyad du 'phags pa slung stong zung 'par yin//

Zhu mkhan shes rab can gyi srangs sum pan de lags//gzhon la khyag pa che ba myil/

Chun gnyer pa yin// bzang lan nar chags gza' ba rnams po yin//mkhas la rkyen pa yar lungs mchod gnas lag//

\section{Observations on the Colophon and What it Tells about Book Production}

This colophon locates the production of the book within the wider Buddhist cosmology and locates the area of production as the land of 'On mo lung ring which is the area where the Ke ru temple is located.

The place name 'On mo lung ring is usually referred to with the short form 'On. 'On is an ancient place name still in use which refers to an area belonging 
to the sKyes pa township of sNe gdong rDzong (county), lHo kha prefecture. Until the 9th century and before the Tibetan kingdom, the 'On area belonged to the sNa nam clan. A powerful and famous clan of that time, sNa nam is mentioned by another colophon of a Ke ru manuscript from the 11th century. Later, some famous monasteries appeared in this area, such as 'On chos sdings and bKra shis do kha.

In terms of the materials used in the production of books, there are references to both paper and ink. Kheng po dung rang remains so far an unclear expression referring to the best quality of paper. A possible explanation is that this was a place name located in the 'Brug yul, current Bhutan. In this context it seems that a place where the Dung rang people lived is indicated. Dung rang is likely to correspond to the tribal group later known as Dung reng, which used to inhabit the Himalayan regions where Bhutan is located. In the $15^{\text {th }}$ century Dung reng people coming from the South invaded the rGyal rtse area (see rGya bod yig tshang 1985: 377, see also an article dedicated to the Dung reng by Petech 1990: 103-111). Keng po can mean 'slaves'. It is therefore likely that with Keng po dung rang a paper from the south, otherwise indicated as lHo shog, was indicated. Manuscripts of 11th-12th centuries also often mention rKong shog, meaning paper from the rKong po area. Near the upper rKong po area, there is a place called sKyems stong (corresponding to current sKyems stong township in sNang county, Nying khri prefecture), which became famous for the production of paper, at least after the 17th century. The paper from this area was made from a particular paper plant named after it: sKyems shing, corresponding to Wikistroemia Canescens, belonging to the Thymealaeaceae (瑞香科 ruixiang ke) family like Daphne, Edgeworthia and Stellera (see Boesi in this volume). sKyems shog was considered to be the source of best quality paper in Tibet. It was used to print paper money by the dGa' ldan pho brang government.

The bSam yas and 'On region was ruled in the 11th century by descendants of Yum brtan who was one of sons of Dar ma 'u dum brtsan (see Bod kyi lo rgyus deb ther khag Inga, 76; see also Tsering Gyalbo, G. Hazod \& P. K. Sörensen 2000: 189 and P. K. Sörensen \& G. Hazod 2005: 314). mNga' bdag mGon ne was regarded as a descendant of Yum brtan. He is celebrated in the colophon, which highlights book production as an important merit making activity at all levels and reflects the fact that this was an expression of royal power and devotion. The extent to which the ruler mGon ne contributed directly to the production of this manuscript is unclear. The scribal workshop was clearly relying on a wider network of people who contributed in different ways and received blessings from participating in this operation. 
Printing workshops, needing a much wider range of resources, represented an enhancement but not necessarily a complete innovation in book production. Networks of patronage were often wide ranging and included people at all levels. As in manuscript production, materials were sourced both locally and through trade. By mapping materials, trade routes and patronage network it will be possible to cast light on hidden aspects of the social history of Tibetan book production and its technological innovations.

\section{References}

Bod kyi lo rgyus deb ther khag lnga (modern print of a collection of historical texts). 1990, Lhasa: Bod ljongs bod yig dpe rnying dpe skrun khang.

Petech, L. 1990. "Dun-ren." Acta Orientalia Hungarica, vol. 44: 103-111.

rGya bod yig tshang chen mo (modern publication of a 15th century). 1985. Chengdu: Si khron mi rigs dpe skrun khang.

Tsering Gyalbo, G. Hazod \& P. K. Sörensen. 200o. Civilization at the Foot of Mount Sham-Po (Beitrage Zur Kultur- Und Geistesgeshichte Asiens). Vienna: Verlag der OeAW.

Sörensen P. K. \& G. Hazod in cooperation with Tsering Gyalbo. 2005. Thundering Falcon: An Inquiry into the History and Cult of Khra-'brug. Tibet's First Buddhist Temple. Vienna: Verlag der OeAW. 